\title{
The Facticity of Symbols: A Reply to Morton Keller
}

\author{
Jeffrey C. Alexander ${ }^{1} \cdot$ Bernadette N. Jaworsky $^{2}$
}

Published online: 13 January 2017

(C) Springer Science+Business Media New York 2016

Indeed, it is certainly not an everyday occurrence, within academia, to engage in such lengthy review-and-response, and we agree with Morton Keller that the subject matter of Obama Power provides one warrant. Obama's 2012 come-from-behind story presents a compelling analytical puzzle. We would like to believe, however, the amplitude also is justified by the second warrant Keller throws out, "the significance and percipience of what the book has to say." While Keller himself seems slightly puzzled by our book, he does not let this haziness get in the way. He has the strong feeling that there is little percipience in Obama Power, and thus not a lot of significance either.

Keller is an accomplished historian. His books about American politics span six decades, most recently Keller (2015). So perhaps his patronizing, old-wine-in-new-bottle tone can be forgiven but perhaps not. Oh come on now, Keller winks to readers, there's really nothin' new here. We already know all about culture. Just look at psychology and economics! Haven't they already done culture? Not to mention-you guessed it-anthropology, which has been studying culture over three centuries!

Keller's platitudinous statements about culture in the disciplines are performatives, not descriptives. Economics and psychology have hardly been fonts of cultural understanding. As for anthropology, its history is filled with bloody intellectual wars over what culture means and how it can be studied. Sure, culture has always been its main topic. So has morality been central to philosophy, but it has still tied thinkers in knots for 2500 years.

Another way to put this is that theory matters. Intellectual arguments are not just headlines: you have to read the fine print. Keller suggests that the "chief basis" for suggesting that Obama Power's "cultural focus adds up to a new interpretation" of empirical events is our emphasis on performance. Not at all. Performance is actually a new perspective inside of the fine-grained debates about culture and collective meaning. Social performance theory is cultural analysis, but the reverse is not the case; cultural analysis is not performance theory. That is the fine print, which can be found in the footnotes of Obama Power-sorry! - and also in the "Note on

Jeffrey C. Alexander

jeffrey.alexander@yale.edu

1 Yale University, New Haven, CT, USA

2 Masaryk University, Brno, Czech Republic 
Concept and Method" to Alexander's The Performance of Politics: Obama's Victory and the Democratic Struggle for Power (2010) and in the hundreds of books and thousands of articles that gradually have constituted the new discipline of cultural sociology over the last three decades. Perhaps one should take notice of some of these before one engages in breezy dismissal.

Keller seems to know little if anything about cultural theory, much less about cultural sociology. And apparently he could not care less, which is a shame. Without knowing from whence we come in Obama Power, it is pretty hard to understand where we are going, much less to evaluate whether we get there. Keller cannot decide whether culture matters. "Not only the concept of cultural sociology, but the book's approach to it," he allows, "has considerable appeal." Yet as one reads through this review essay, one hears the inimitable words of Detective Joe Friday, the hero of the 1950s police procedural Dragnet: "We just want the facts, ma'am, nothing but the facts." Keller is aware that narrative and framing matter, yet he is continually juxtaposing them to what he views as the "raw facts" of social life. Obdurate facts on the ground resist the gloss of symbolization, he firmly believes: the real must be studied apart from representation.

Consider Keller's response to our reconstruction of the narrative Obama deftly deployed to frame his Republican opponent Mitt Romney. He begins with this, paraphrasing and quoting Obama Power:

Obama sought to champion democratic morality, sustain social solidarity, protect free people from oppression, consign his Republican opponent Mitt Romney "outside the world of civility into the immoral world outside," and portray Romney as the "very embodiment of anti-solidarity." They [Alexander and Jaworsky] speak of Romney's "damaging anti-civil vision." Obama offered in its stead "a broadly civil rather than a narrow, more primordial solidarity."

Keller is skeptical: "This seems to be something of a stretch." Why? Because the facts about Romney do not align with Obama's framing: "Romney, after all, was a fairly successful governor of true-Blue Massachusetts. And he was far indeed from being the reddest in tooth and claw among the 2012 GOP aspirants." But is not this exactly our cultural-sociological point? Facts themselves do not speak: they must be spoken about. Here was a man who had been a moderately cosmopolitan, relatively reformist Massachusetts governor, and just look what Obama was able to make of him in 2012. The democratic president told a radically different story, and he made it stick.

Acknowledging Romney is "immensely wealthy," Keller asks "how distinctive — or indeed, germane - is this in a political world where politicians such as Al Gore and the Clintons are at least equally well-heeled?" How germane is, and was, a matter for audiences to decide, and for performers to frame. It is not something decided by an observer from the outside. Maybe Al Gore and the Clintons are as wealthy as the Romneys, but that is certainly not how the two liberal icons were publicly understood. Strangely enough, even as Keller asserts the supreme stickiness of brute facts, he folds his cards: "That the Democrats effectively (with big own-goal assists from Romney himself) portrayed the GOP candidate as the embodiment of plutocratic indifference to the needs and wants of the common folk, is incontestably true." Portrayal is the key. What seemed like an unlikely stretch to Romney's Republican supporters seemed incontestably true to the American majority.

In Obama Power, we detail the Democrats' symbolic construction of the Republican frontrunner as a Bain capitalist out of touch with ordinary Americans. Morton asks whether "this not be seen as another chapter in a venerable American political tradition of successful 
opposition-smearing, rather than a distinctive form of symbolic stereotyping." This is a distinction without a difference. Certainly, painting the opposition in the glaring colors of the enemy is not new to electoral politics, nor do we ever make this claim. It is (and always has been) a distinctive form of symbolic stereotyping. Our point is to reveal the cultural work underpinning this venerable process of smearing/pollution.

Consider the case of the Ryan budget. In the wake of the Republicans' legislative triumph in 2010, Representative Paul Ryan, the deeply conservative policy wonk, proposed a smoke and mirror budget which would have restored tax cuts for wealthy Americans and cut social programs for others. One of the most unexpected findings of Obama Power is that the President fuelled his post-2010 political recovery by making mincemeat of this budget proposal. The symbolic knife fight occupied America's political stage for much of 2011, and, when the performance concluded, Ryan laid prostrate, Obama's boot on his throat, and Obama's sword at his heart. Keller misreads this finding as an exercise in realism: "The authors find in Paul Ryan, 'the darling of the Tea Party,' the embodiment of the take-noprisoners GOP opposition. His budget proposals, they imply, justified the push-grandma-overthe-cliff imagery of an anti-Ryan TV ad." But it is Obama who made these claims, not us. Our argument cuts exactly the other way: what Ryan's budget would or would not do-down the line - could only be a matter of conjecture. Nothing could be proved in the present time. What mattered was portrayal. By virtue of felicitous performance, Obama made his claim that Ryan was a grandma-torturing Neanderthal seem not like a claim, but a fact.

Keller challenges our argument by pointing to different facts, suggesting, "surely there was more to Ryan, and his budget ideas, than that." While "there was every reason to criticize them," to "consign them beyond the pale of accepted political discourse was hardly in tune with the theme of Obama's appeal to universalism and solidarity." But who decides whether a performance is in tune? It is the audience, not some pitch perfect observer. Political performers try to harmonize as best they can. Putting Ryan's budget beyond the pale can, after all, be interpreted as consistent with democratic solidarity if that budget is portrayed as selfish, meanspirited, and elitist. That, of course, was exactly Obama's performative effect.

Or consider Obamacare, the passage of which preoccupied the first 2 years of Obama's presidency. The Democratic president intended to make Obamacare Exhibit A of his promise to effect "real change, change you can believe in," which, from the left perspective, means expanding civil solidarity. Critical to our argument in Obama Power is that this political performance fell fatally short, that the president failed, and here Keller is quoting, "to energize the feelings of solidarity that were necessary to legitimate institutional change." Keller's response is revealing. While our reference to Obama's performative failure "is perceptive," it "devalues concrete (as distinct from cultural) concerns about cost, coverage, and access that have bedeviled Obamacare since its inception."

Does Obama Power devalue such concrete facts, or does it suggest, rather, that judging whether such claims are actually factual and concrete, instead of hyperbolic and speculative, is a matter of collective representation? Writing for the web pages of the Hoover Institution, the conservative Stanford think tank (Keller 2011a; Keller, 2014) had predicted Obamacare would self-destruct, describing it as a bureaucratic mess. Here, he continues to dispute the factual status of Obama's liberal claims: "It may fairly be asked if [Obama's] promises of reduced costs, and of keeping your policy and your doctor if you so chose, were indeed 'facts'." Who is asking? Not some neutral observer but a scholar who was, and still is, himself deeply engaged in partisan debate. So much for the question being "fairly asked." But our principal argument here is theoretical, not ideological. The facts about Obamacare tout court were, and are, 
impossible to determine objectively. "Its success is still to be determined," Keller acknowledges, and that is precisely the point. History cannot wait. Politics must be played here and now. The language game requires engaging in performances that transform yet-to-bedetermined possibilities into seemingly undeniable facts. Who performs felicitously wins elections and seizes state power.

The voting public's concerns about cost, coverage, and access are filtered through the background reservoir of collective representations that inform its choices and decisions. In theoretical terms, it is the difference between a sociology of culture and a cultural sociology. In the former, culture is a "weak" or, in positivistic terms, a dependent variable. Instead, we see culture as an independent variable, possessing the same explanatory power as other social structures of a more material kind.

Keller professes to worry that, with our metaphor of the microscope as a means to dig deep into the texture of social process, we have abandoned the broader view of the telescope. Saying that "contingency, issues, and get-out-the-vote machinery are consigned to a secondary status," as mere "instruments for implementing the appeal of the candidate's cultural message," he claims to challenge the premises of such an approach. But, we hardly suggest such factors are secondary; indeed, they are our principal focus throughout the book. What we aim to demonstrate, rather, is that such social processes are refracted through the lens of culture. They are speech acts (paroles) that creatively bring broader culture structures (langues) to bear on the rapidly changing complexities of concrete political, economic, religious, ethnic, and military scenes. Only through carefully reconstructing such meaning-related speech acts can we disentangle the biways of political communication.

Keller accuses us of having a Manichean view of politics that is "as distorting today as it was in the past." To demonstrate such, he once again references what he takes as brute reality: "The fact of the matter is that our politics has a framework that fosters structural and operational similarity as readily as it fosters ideological difference." The evidence for this assertion? George Soros, Tom Steyer, and the Koch brothers, GOP-leaning Wall Street and Democratic-leaning Hollywood and Silicon Valley and Congressional leaders of different parties are, Keller argues, "functionally similar, however much they differ over policy" (italics added). But functional similarity is orthogonal to the performance of politics. What is critical to take on board is that, when they struggle for power, social actors strive to perform difference. Meaning-making is all about contrast, and those who compete to demonstrate that it is they who embody the universalizing ideals of the civil sphere seek to portray their opponents as wholly anti-civil. The Koch brothers are evil; George Soros is sacred. Or is the other way around? It is up to citizen audiences to say. It is paradoxical that such antipathies can be constructed only against the background of a shared, overarching, and highly generalized symbolic code. The empirical challenge is that, like any language, the discourse of civil society is invisible. It is a whole imputed from visible parts, an absence in Derrida's terms. Difference, by contrast, is highly visible. It is a presence, but it cannot be deployed without reference to the absent language of which it forms a part. Hence Dilthey's hermeneutic circle.

Our view of culture accords it a place of privilege in social scientific analysis. To believe in a truly cultural sociology is to also believe that culture is a thread than through every conceivable social form. There is nothing that is acultural. We challenge Keller's strict separation of culture from more "real" social facts. Referring to 
Obama's post-2008 decline, Keller writes, "Quite properly they [Alexander and Jaworsky] ascribe Obama's fall from symbolic grace not only to GOP obscurantism, but also to the quite non-symbolic fact of a weak and halting economy stubbornly refusing to get back on its feet, as it had done so often before." The economy is hardly non-symbolic. As we point out in Obama Power, "the economy delivers cultural as well as symbolic goods-the hopes and anxieties that affect what Keynes called capitalism's 'animal spirits'." Social facts themselves (like a weak economy) do not speak. Without the mediation of cultural representation, material causes can have only limited social effect.

Keller's obsession with social facts, however, does not prevent him from sometimes playing fast and loose with them himself. In his struggle to minimize Obama's 2012 victory and, thus, our claims about the president's performative power, he points out that Obama "did only a bit more than half as well as 4 years before." He goes on to assert, "The only previous instances in modern American political history when a sitting president failed to increase his margin were Herbert Hoover in 1928 and George H.W. Bush in 1992: hardly meaningful analogs to Obama in 2014." But, surely, Jimmy Carter did not increase his margin when he lost to Ronald Reagan in 1980! And then there is somebody named Franklin Delano Roosevelt, whose margin of victory dropped in both 1940 and 1944.

Another factual issue concerns the high unemployment rate hanging over Obama's head. Keller throws out an accusation and a laundry list of other elections in which the unemployment rate was presumably problematic, with the goal, once again, of undercutting our claims about the magnitude of Obama's performative success: "When the authors observe that unemployment soared to a height that 'prevented any previous sitting President since FDR from being re-elected,' it is not clear why Ronald Reagan's 1984 re-election (or for that matter Eisenhower's in 1956, Nixon's in 1972, Clinton's in 1996, or George W. Bush's in 2004) should be so cavalierly ignored." At issue throughout the 2012 campaign season was whether unemployment would ever get below $8 \%$. Let us see if these other campaigns were in the same league. According to the Bureau of Labor Statistics, when Eisenhower was elected in November 1956, the unemployment rate was $4.3 \%$, having dropped over the past year and a half, from $4.9 \%$ in January 1955 . What is more, while the economy had fared better under Truman than Eisenhower's first term, real GDP had grown 7.14\% in 1955. As Nixon stood for re-election in 1972, the $5.3 \%$ unemployment rate had been dropping for about a year. For Reagan in 1984, the relatively high $7.2 \%$ unemployment rate, although $2 \%$ higher than the previous administration, had been dropping from a high of $10.8 \% 2$ years prior. And while in 1996 and 2004, the rate was 5.4\%, it too had been improving.

Yes, we are cultural sociologists interested primarily in meaning making, but we stand ready to wrangle over accuracy in the evidence we marshal to support our claims. If you claim the factual high ground, you would better be right. There be dragons there. If you get facts wrong, you are not a truth teller but a fact-monger.

Back in 2011, Keller (2011b) predicted that Obama's policy failures were contributing to what he dubbed an imminent "anti-progressive" revolution in American politics. Interpreting the Democrats' 2010 mid-term debacle in realist terms, he predicted Obama would follow in the footsteps of Jimmy Carter, defeated in 2012 and remembered as a tarnished totem, a loser, a one-term president. Why that did not happen is what we wrote Obama Power to explain. Keller is as mistaken about our book as he was about Obama's fate. It is not only that he has got the facts of our book wrong but also that he lacks the theoretical understanding to perceive their frame. 


\section{References}

Keller, Morton. 2011a. "The unbearable heaviness of governing." Hoover Digest. Hoover Institution. January 12. http://www.hoover.org/research/unbearable-heaviness-governing. Retrieved 2/4/16.

Keller, Morton. 2011b. "The anti-progressive era." Advancing a Free Society. Hoover Institution. May 18. http://www.hoover.org/research/anti-progressive-era. Retrieved 2/4/16.

Keller, Morton. 2014. “America stalled.” Defining Ideas. Hoover Institution. September 25.http://www.hoover. org/research/rise-and-stall-american-state. Retrieved 2/4/165.

Keller, M. (2015). Obama’s time: a history. New York: Oxford University Press. 